\title{
Health Care Professionals' Opinions and Expectations of Clinical Pharmacy Services on a Surgical Ward
}

\author{
Bernadette Chevalier, Heather L Neville, Kara Thompson, Lisa Nodwell, and Michael MacNeil
}

\begin{abstract}
Background: Pharmacists have made significant contributions to patient care and have been recognized as integral members of the interprofessional team. Health care professionals differ in their opinions and expectations of clinical pharmacy services. Very little has been published about health care professionals' perspectives on advanced clinical pharmacy roles, such as prescriptive authority or administration of vaccines. In 2013, clinical pharmacy services were introduced in a vascular and general surgery ward where a pharmacist had not previously been assigned.
\end{abstract}

Objectives: To explore surgical nurses' and physicians' opinions and expectations of clinical pharmacy services and to determine how these views changed over time; to compare pharmacists' views of clinical pharmacy services with those of nurses and physicians; and to develop validated survey tools.

Methods: Three survey tools were created and validated, one for each profession. Surveys were distributed to nurses and physicians assigned to the general and vascular surgery ward before introduction of clinical pharmacy services and 8 months after implementation. Hospital pharmacists were invited to complete the survey at one time point.

Results: Differences existed in the opinions of nurses, physicians, and pharmacists about some traditional activities. Nurses and physicians indicated stronger agreement with pharmacists participating in medication reconciliation activities than did pharmacists $(p<0.001)$, whereas a greater proportion of pharmacists felt that they were the most appropriate health care professionals to provide medication discharge counselling, relative to nurses and physicians $(p=0.001)$. Respondents supported advanced roles for pharmacists, such as collaborative practice agreements, but there was less support for prescribing, physical assessments, and administration of vaccines. Nurses indicated the strongest agreement with pharmacist prescribing ( $82 \%$ versus $69 \%$ among pharmacists and $27 \%$ among physicians; $p<0.001)$. Nurses and physicians expressed strong endorsements of clinical pharmacy services in the surveys' comment sections.

Conclusions: The introduction of clinical pharmacy services to a surgical health care team resulted in high levels of satisfaction among nurses and physicians who responded to this survey. Differences in perceptions of traditional clinical pharmacy service activities and advanced practice roles need to be studied in more depth to better understand the factors influencing health care professionals' views.

Keywords: survey, clinical pharmacy services, roles, interprofessional team, surgery

\section{RÉSUMÉ}

Contexte : Les pharmaciens ont fait d'importantes contributions aux soins aux patients et ils ont d'ailleurs été reconnus comme membres à part entière de l'équipe interprofessionnelle. Les professionnels de la santé ont des opinions et des attentes variées en ce qui concerne les services de pharmacie clinique. Or, il n'y a que très peu de documents publiés à propos des points de vue soutenus par les professionnels de la santé sur les rôles en pharmacie clinique avancée, notamment le droit de prescrire et l'administration de vaccins. En 2013, des services de pharmacie clinique ont fait leur entrée dans une unité de chirurgie générale et vasculaire où aucun pharmacien n'avait été affecté auparavant.

Objectifs : Chercher à connaitre l'opinion et les attentes du personnel médical et infirmier rattaché à une unité de chirurgie en ce qui concerne les services de pharmacie clinique et voir comment ces perceptions ont changé avec le temps; comparer les points de vue soutenus par les pharmaciens en ce qui concerne les services de pharmacie clinique à ceux du personnel médical et infirmier; et mettre au point des outils d'enquête validés.

Méthodes : Trois outils d'enquête ont été créés et validés, un pour chaque profession. Les sondages ont été distribués au personnel médical et infirmier rattaché à l'unité de chirurgie générale et vasculaire avant l'introduction de services de pharmacie clinique, puis huit mois après la mise en place de ces services. Les pharmaciens d'hôpitaux ont été invités à répondre au sondage à un point dans le temps.

Résultats : On a observé des différences entre les opinions du personnel infirmier, des médecins et des pharmaciens à propos de certaines activités traditionnelles. Le personnel infirmier et les médecins ont indiqué être plus fortement d'accord avec la participation des pharmaciens aux activités touchant le bilan comparatif des médicaments que ne l'ont signalé les pharmaciens $(p<0,001)$, alors qu'une plus grande proportion de pharmaciens croyaient être les professionnels de la santé les mieux placés pour offrir des conseils sur les médicaments au moment du congé, comparativement au personnel infirmier et aux médecins $(p=0,001)$. Les répondants étaient favorables aux rôles avancés pour les pharmaciens, comme les ententes de pratique en collaboration, mais ils l'étaient moins en ce qui touche à la prescription, à l'examen physique et à la vaccination. Le personnel infirmier était le plus d'accord avec le droit de prescrire des pharmaciens ( $82 \%$ contre $69 \%$ pour les pharmaciens et $27 \%$ pour les médecins; $p<0,001)$. Le personnel infirmier et les médecins ont exprimé un fort appui pour les services de pharmacie clinique dans les sections du sondage réservées aux commentaires. 


\section{Can J Hosp Pharm. 2016;69(6):439-48}

Conclusions : La mise en place de services de pharmacie clinique dans une équipe de soins de santé en chirurgie s'est traduite par des niveaux élevés de satisfaction chez le personnel infirmier et les médecins ayant répondu à ce sondage. Les différences des perceptions à l'égard des activités traditionnelles de services de pharmacie clinique et les rôles de pratique avancée doivent être étudiées plus en profondeur afin de mieux comprendre les facteurs qui influencent les points de vue des professionnels de la santé.

Mots clés : sondage, services de pharmacie clinique, rôles, équipe interprofessionnelle, chirurgie

\section{INTRODUCTION}

$\mathrm{T}$ he role of pharmacists in health care settings has evolved over the past 40 years, with a shift from drug dispensing responsibilities to the provision of direct patient care. ${ }^{1}$ Pharmacists have made significant contributions to patient care and have been recognized as integral members of the interprofessional team..$^{2-5}$ Changes to Canadian regulations have expanded pharmacists' scope of practice to include broader prescriptive authority and the administration of vaccinations..$^{6-8}$ In parts of North America and the United Kingdom, hospital pharmacists have engaged in collaborative practice agreements with physician colleagues to allow further prescriptive authority. ${ }^{9,10}$ These collaborative practice agreements between pharmacists and physicians have been described as formal legal arrangements defining the circumstances under which pharmacists may assume responsibilities for medication management, such as prescribing and ordering laboratory tests. ${ }^{\text {? }}$

These ongoing changes in pharmacists' scope of practice may affect how other health care professionals view pharmacists' roles or their expectations of clinical pharmacy services. Published surveys of nurses and physicians working with pharmacists in various settings have focused on their satisfaction with services, with less emphasis on their opinions and expectations of the role of pharmacists providing direct patient care. ${ }^{11-13}$

Very little has been published about the opinions of nurses and physicians working in various surgical areas. ${ }^{14,15}$ Clinical pharmacy services and advanced practice roles, such as expanded prescriptive authority, may be of particular benefit to staff on surgical wards, where access to physicians may be limited because of surgical duties and responsibilities. Having a ward pharmacist available to focus on patients' pharmacotherapeutic needs may also be beneficial to nurses' and physicians' own professional practice.

Although there is some literature about other health care professionals' opinions of clinical pharmacy services, few studies have included hospital pharmacists' perceptions of their own role. ${ }^{11,16-18}$ Even less has been published on hospital pharmacists' perspectives on expanding scopes of practice. ${ }^{19-21}$ However, the survey tools used in these previous studies were not validated for internal consistency or reliability.

Comparing pharmacists' opinions about advanced practice roles for pharmacists with the opinions of other health care colleagues may provide valuable information about the colleagues' receptivity to such roles and how they perceive the value or importance of these roles. In addition, the views of pharmacists, nurses, and physicians about advanced practice roles for pharmacists may help to inform pharmacy leadership in decisions about expanding clinical pharmacy services, indicate the readiness of staff for change, and identify areas where education is required.

In 2013, clinical pharmacy services were introduced to a surgery unit at the authors' institution, where no clinical pharmacist had previously been assigned. The aims of this study were to explore nurses' and physicians' opinions and expectations of clinical pharmacy services before and after their implementation within the unit; to compare the views of nurses, physicians, and pharmacists about clinical pharmacy services; and to create validated survey tools.

\section{METHODS}

The study institution was a 950-bed adult tertiary care facility that serves a local population of 400 000, providing specialist services in the region. ${ }^{22}$ The pharmacy department provides both drug distribution and clinical pharmacy services to the institution.

The pharmacy also provides clinical services to numerous patient care areas, including intensive care, hematology-oncology, emergency, transplant unit, cardiology, medicine, gastrointestinal surgery, geriatrics, mental health, and some ambulatory areas such as hemodialysis and HIV clinics. For areas that do not receive clinical services, health care providers access pharmacists through the main pharmacy to obtain answers to drug-related queries, such as drug information and medication-administration questions. 
In late April 2013, clinical pharmacy services were introduced to a 27-bed vascular and general surgery patient care area, where no clinical pharmacist had previously been assigned. Under the new model, one pharmacist provided clinical pharmacy services on weekdays only. The scope of services provided depended on the ward's clinical service requirements and the pharmacist's training and experience, with additional guidance from clinical pharmacy practice standards. ${ }^{23,24}$ The pharmacist also reviewed and electronically entered all medication orders on the ward, which allowed any prescription-related issues to be addressed at the source.

\section{Survey Development}

Three survey tools, one for each profession, were developed on the basis of previous research, ${ }^{15}$ with additional statements about advanced pharmacy practice, such as prescribing authority, collaborative practice agreements, administration of vaccines, and physical assessments.

The surveys for nurses and physicians included statements evaluating 2 domains: self-efficacy and disconfirmation of expectations (expected roles of pharmacists). In the context of this study, the self-efficacy domain included statements about how the presence of a pharmacist addressing medication issues on the ward might affect nurses' or physicians' professional confidence and ability to focus on their own professional roles. The survey for pharmacists comprised statements about expectations only. The rationale for these domains was based on satisfaction survey research ${ }^{25,26}$ and a previous survey of nurses with questions about their expectations of clinical pharmacy services and how those services affected nursing responsibilities. ${ }^{27}$ Further details about original survey development and the rationale for the domains have been previously reported. ${ }^{15}$

Each survey consisted of 3 main sections. Expectations of clinical pharmacy services and views related to self-efficacy were covered in section A, where respondents were asked to indicate agreement or disagreement with various statements using a 5-point Likert scale. Section B collected background and demographic information, and section $\mathrm{C}$ offered an area for comments.

\section{Survey Validation}

To ensure face and content validity, draft versions of the surveys were distributed to groups of nurses, physicians, and pharmacists experienced in surgery, but outside the intended study group, to obtain their input on content and wording. Adjustments were then made to the surveys to ensure that statements would be interpreted as intended.

To provide assurance of internal consistency within the survey domains, Cronbach $\alpha$ reliability testing was conducted. The Cronbach $\alpha$ measures internal consistency or the extent to which test items (or statements) within a category (or domain) are interrelated. Strong correlations between statements within the same domain indicate good internal consistency and result in higher Cronbach $\alpha$ values. ${ }^{28}$ Reported acceptable Cronbach $\alpha$ values range from 0.60 or greater ${ }^{29}$ to 0.70 or greater. ${ }^{28}$

To perform Cronbach $\alpha$ reliability testing, a sample of at least 27 respondents was required to achieve $90 \%$ power to detect the difference between the coefficient $\alpha$ under the null hypothesis of 0.50 and the coefficient $\alpha$ under the alternative hypothesis of 0.80 using a 2 -sided $F$-test with a significance level of 0.05 .

To achieve this sample size, the surveys were piloted with 32 nursing staff and 27 pharmacists from other hospitals and 28 surgeons and residents from other areas of Capital Health. The responses of these pilot groups were assessed for reliability of measures by Cronbach $\alpha$. This analysis was repeated for the study population.

\section{Survey Administration}

The surveys for nurses and physicians were distributed to all nursing staff and all physicians, respectively, assigned to the vascular and general surgery ward in April 2013, before the introduction of clinical pharmacy services; the same professionspecific surveys were distributed to these 2 professional groups in January 2014, 8 months after implementation of clinical pharmacy services. This interval between surveys was selected to allow development of interprofessional relationships and establishment of a clear role for the pharmacist within the health care team. All registered nurses, licensed practical nurses, and vascular and general surgery staff physicians and residents on the study ward were eligible to participate. The pharmacist survey was distributed to all departmental pharmacists in June 2013.

Each survey was distributed over a 1-month period, with 2 weekly email reminders; the surveys were made available in paper and electronic formats. Participation was entirely voluntary. The surveys required about 10-15 min to complete. Nominal gift cards were distributed to respondents upon survey completion. The Capital Health Research Ethics Board considered this study to be quality assurance research, which did not require formal approval.

\section{Data Analysis}

All data were entered into a Microsoft Access database (Microsoft Corp, Redmond, Washington) for analysis by SAS statistical software, version 9.2 (SAS Institute, Cary, North Carolina), except for Cronbach $\alpha$ reliability results for the study population, which were analyzed using RStudio software, version 3.2.0 (RStudio, Inc, Boston, Massachusetts). For the demographic data, $p$ values less than 0.05 were considered statistically significant. However, for all reported outcomes, critical $p$ values less than 0.001 (based on a Bonferroni adjustment due to 71 comparisons) were considered statistically significant. All surveys were included 
in the analysis, including those with missing responses for some statements. Responses for the "before" survey had no identifiers that would allow them to be matched to responses for the "after" survey.

For each statement, the data were expressed as the percentage of all responses that were positive (Agree + Strongly Agree or, in the case of reverse-worded statements, Disagree + Strongly Disagree). The Fisher exact test was used to test associations between "before" and "after" survey responses and "before" and "after" demographic characteristics. Mean rank scores were tabulated from the "after" survey responses for nurses, physicians, and pharmacists and were tested for differences using the KruskalWallis test.

Responses from the "after" survey were chosen for comparison across professions, as these were thought most likely to represent the most current opinions of health care professionals. Comments from the "after" survey were grouped by theme, each of which was exemplified by one or more statements.

\section{RESULTS}

\section{Internal Consistency (Cronbach $\alpha$ Reliability)}

The Cronbach $\alpha$ reliability results for both the pilot and study population groups are shown in Table 1. For the study groups, Cronbach $\alpha$ was greater than 0.7 for both domains, indicating acceptable reliability.

\section{Respondent Characteristics}

A total of 25 (45\%) of the 56 eligible nurses and 6 (23\%) of the 26 eligible physicians completed their respective survey before clinical pharmacy services were implemented, and 63\% (35/56) of the nurses and 58\% (15/26) of the physicians completed their respective survey after implementation. Fifty-three (69\%) of the 77 eligible pharmacists completed the pharmacist survey. The mean completion rates for survey questions were $100 \%$ by physicians, $97 \%$ by nurses, and $91 \%$ by pharmacists.

There were no significant differences in the demographic characteristics of nurses completing the survey before and after implementation of clinical pharmacy seervices (Table 2). Among physicians, there were more resident or student respondents to the "after" survey than the "before" survey $(p=0.05)$.

\section{Survey Results}

Among the self-efficacy statements (Table 3), the majority of nurses and physicians agreed that having a pharmacist present to help manage medication issues allowed them to feel more confident and better able to concentrate on their own professional roles. Within each profession, these opinions did not change following implementation of clinical pharmacy services $(p>0.05$ for all comparisons between "before" and "after" surveys).

Results from the "before" and "after" surveys of nurses and physicians are compared with results from the pharmacist survey in Table 4. Nurses' and physicians' expectations of pharmacists did not change significantly after the introduction of clinical pharmacy services. However, the opinions of nurses, physicians, and pharmacists differed significantly in a number of areas. Mean rank scores for both nurses and physicians indicated stronger agreement (relative to pharmacists) with pharmacists participating in medication reconciliation activities $(p<0.001)$. Pharmacists placed significantly more value on ensuring that patients receive optimum drug therapy $(p<0.001)$, on identifying and resolving drug-related problems $(p<0.001)$, and on recommending dosage adjustments $(p<0.001)$; they also felt (to a greater extent than did nurses and physicians) that they were the most appropriate health care professionals to provide medication discharge counselling $(p=0.001)$.

Nurses and physicians were less likely than pharmacists to support pharmacists conducting physical assessments $(p<0.001)$. Nurses indicated stronger agreement with the concept of pharmacists having prescribing responsibility relative to either pharmacists or physicians $(p<0.001)$. Larger proportions of nurses and physicians than of pharmacists agreed with collaborative practice agreements for pharmacists $(p<0.001)$.

Comments in the "before" surveys were sparse, but numerous comments expressing support and enthusiasm for clinical pharmacy services were provided in the "after" surveys. Two main themes emerged from physicians' comments.

Table 1. Internal Consistency (Reliability)

\begin{tabular}{|c|c|c|c|c|}
\hline & \multicolumn{2}{|c|}{ Expectations Domain } & \multicolumn{2}{|c|}{ Self-Efficacy Domain } \\
\hline & No. of Statements & Cronbach $\alpha$ & No. of Statements & Cronbach $\alpha$ \\
\hline \multicolumn{5}{|l|}{ Pilot } \\
\hline Nurses $(n=32)$ & 20 & 0.77 & 7 & 0.66 \\
\hline Physicians ( $n=28$ ) & 20 & 0.83 & 7 & 0.82 \\
\hline Pharmacists $(n=27)$ & 22 & 0.81 & NA & NA \\
\hline \multicolumn{5}{|l|}{ Study } \\
\hline Nurses $(n=35)$ & 20 & 0.88 & 7 & 0.72 \\
\hline Physicians ( $n=15$ ) & 20 & 0.74 & 7 & 0.74 \\
\hline Pharmacists $(n=53)$ & 22 & 0.88 & NA & NA \\
\hline
\end{tabular}




\section{Table 2. Demographic Characteristics of Study Participants}

\begin{tabular}{|c|c|c|c|c|}
\hline \multirow[t]{2}{*}{ Profession and Role } & \multicolumn{3}{|c|}{$\begin{array}{l}\text { Work Experience; } \\
\text { No. (\%) of Respondents* }\end{array}$} & \multirow{2}{*}{$\begin{array}{l}\text { No. (\%) Who Previously } \\
\text { Worked with Clinical } \\
\text { Pharmacist }\end{array}$} \\
\hline & $<5 \mathrm{yr}$ & $6-10 \mathrm{yr}$ & $>10 \mathrm{yr}$ & \\
\hline \multicolumn{5}{|l|}{ Nurses } \\
\hline \multicolumn{5}{|l|}{ "Before" survey $(n=25)$} \\
\hline $\operatorname{RN}(n=21[84 \%])$ & 8 & 5 & 8 & 4 \\
\hline $\operatorname{LPN}(n=4[16 \%])$ & 0 & 1 & 3 & 0 \\
\hline Total & $8(32)$ & $6(24)$ & $11(44)$ & $4(16)$ \\
\hline \multicolumn{5}{|l|}{ "After" survey $(n=35)$} \\
\hline $\operatorname{RN}(n=31[89 \%])$ & 16 & 4 & 11 & 5 \\
\hline $\operatorname{LPN}(n=4[11 \%])$ & 0 & 1 & 3 & 1 \\
\hline Total & $16(46)$ & $5(14)$ & $14(40)$ & $6(17)$ \\
\hline \multicolumn{5}{|l|}{ Physicians } \\
\hline \multicolumn{5}{|l|}{ "Before" survey $(n=6)$} \\
\hline Staff $(n=5[83 \%])$ & 1 & 2 & 2 & 3 \\
\hline Student/resident ( $n=1$ [17\%]) & 1 & 0 & 0 & 1 \\
\hline Total & $2(33)$ & $2(33)$ & $2(33)$ & $4(67)$ \\
\hline \multicolumn{5}{|l|}{ "After" survey $(n=15)$} \\
\hline Staff $(n=4[27 \%])$ & 0 & 2 & 2 & 2 \\
\hline Student/resident ( $n=11$ [73\%]) & 11 & 0 & 0 & 9 \\
\hline Total & $11(73)$ & $2(13)$ & $2(13)$ & $11(73)$ \\
\hline \multicolumn{5}{|l|}{ Pharmacists $(n=53)$} \\
\hline BScPharm $(n=28[53 \%])$ & 1 & 4 & 23 & NA \\
\hline Post-BScPharm† ( $n=25$ [47\%]) & 7 & 3 & 15 & \\
\hline Total & $8(15)$ & $7(13)$ & $38(72)$ & \\
\hline
\end{tabular}

LPN = licensed practical nurse, $\mathrm{RN}=$ registered nurse.

*Percentages were calculated only for the "total" rows, based on the $n$ value for the combination of role and time of survey (before or after implementation of clinical pharmacy services), as applicable.

tExamples include residency, PharmD, MSc.

(1) Pharmacists represent a drug therapy and information resource:

"[Pharmacists] are very knowledgeable and have provided an important service to the team. They also independently seek out answers and solutions for any problems/question we ask about."

(2) Pharmacists play a role in improving patient safety: "These people catch morbid medication mistakes on a daily, if not hourly basis."

"They regularly pick up med discrepancies and bring them to the attention of the Residents."

Not all of the physicians' comments were favourable. One physician expressed concern that pharmacists contributed to patients' confusion about health care professionals' roles:

"Patients are also getting many messages from various team members without an appreciation of the person's role on the team .... and therefore advice given on the weekend that contradicts information given through the week is confusing to the patients."
Nurses' comments were grouped into 3 main themes.

(1) Pharmacists serve as an important drug therapy and information resource:

"Our clinical pharmacist is very approachable and knowledgeable.”

"They have been overly helpful with questions and helping patients with all of their questions."

(2) Pharmacists help to improve patient care and safety: "I believe that med errors are fewer and continuity of care from home to hospital to home again has improved greatly because of [his/her] involvement on our team."

"Patients are more knowledgeable upon discharge regarding medications and their safety."

(3) Pharmacists were accessible and improved efficiency (a theme unique to the nurses' survey):

"...having a pharmacist available on the floor has been very helpful and timesaving." 
This single copy is for your personal, non-commercial use only.

For permission to reprint multiple copies or to order presentation-ready copies for distribution, contact CJHP at cjhpedit@cshp.ca

\section{Table 3. Self-Efficacy: How Clinical Pharmacists Can Enhance Nurses' and Physicians' Practice}

\begin{tabular}{|c|c|c|c|c|c|c|}
\hline \multirow[b]{3}{*}{ Statement } & \multicolumn{6}{|c|}{ Profession; Timing; \% with Agree* Response } \\
\hline & \multicolumn{3}{|c|}{ Nurses } & \multicolumn{3}{|c|}{ Physicians } \\
\hline & $\begin{array}{l}\text { "Before" } \\
\text { Survey } \\
(n=25)\end{array}$ & $\begin{array}{l}\text { "After" } \\
\text { Survey } \\
(n=35)\end{array}$ & $p$ Value & $\begin{array}{l}\text { "Before" } \\
\text { Survey } \\
(n=6)\end{array}$ & $\begin{array}{l}\text { "After" } \\
\text { Survey } \\
(n=15)\end{array}$ & $p$ Value \\
\hline $\begin{array}{l}\text { Having a clinical pharmacist on patient care rounds to } \\
\text { answer questions about patients' medications would } \\
\text { allow/allows me to concentrate on my professional } \\
\text { responsibilities. }\end{array}$ & $92 \%$ & $94 \%$ & $>0.99$ & $83 \%$ & $87 \%$ & $>0.99$ \\
\hline $\begin{array}{l}\text { I would be/am more confident in my own practice if a } \\
\text { clinical pharmacist was available on the nursing unit } \\
\text { to answer drug information or administration questions. }\end{array}$ & $100 \%$ & $97 \%$ & $>0.99$ & $67 \%$ & $93 \%$ & 0.18 \\
\hline $\begin{array}{l}\text { I would/do feel more confident in my own practice if a } \\
\text { clinical pharmacist assisted me with discharge planning. }\end{array}$ & $64 \%$ & $69 \%$ & 0.79 & $67 \%$ & $87 \%$ & 0.54 \\
\hline $\begin{array}{l}\text { Education on drug topics by pharmacist would enhance } \\
\text { my professional practice. }\end{array}$ & $92 \%$ & $91 \%$ & $>0.99$ & $100 \%$ & $93 \%$ & $>0.99$ \\
\hline $\begin{array}{l}\text { I would be/am more confident in providing quality } \\
\text { care to my patients if I knew a clinical pharmacist has } \\
\text { reviewed my patients' medications for appropriateness } \\
\text { (dose, indication, route, duration) as well as potential } \\
\text { drug interactions, drug-disease interactions and allergies. }\end{array}$ & $100 \%$ & $100 \%$ & $>0.99$ & $83 \%$ & $93 \%$ & 0.50 \\
\hline
\end{tabular}

“[He/she] gives us more time to do direct patient care."

To improve clinical pharmacy services, the pharmacists recommended more consistent clinical coverage and a better understanding of health care professionals' roles:

"Improving physician/nursing knowledge of what contri-

butions a clinical pharmacist can make to the team."

\section{DISCUSSION}

Nurses and physicians showed support of and satisfaction with dedicated clinical pharmacy services provided to a surgical health care team. Validated surveys allowed nurses and physicians to provide their opinions of clinical pharmacy services before and after implementation of such services, and the opinions of these health care professionals were compared with pharmacists' opinions about their own clinical role. Nurses and physicians expressed strong assertions about pharmacists' impact on patient safety and their value as drug therapy and information experts. Nurses also highlighted the positive impact of pharmacists on workflow efficiency and improved quality of patient care.

The main strength of this study was that it built substantially on previous work ${ }^{15}$ by including the opinions of physicians, as well as those of nursing staff, in evaluating new clinical pharmacy services. In addition, the study compared pharmacists' perspectives with those of nurses and physicians, and the surveys covered advanced practice roles, to reflect the expanded scope of pharmacy practice. Another strength of this study was its use of 3 validated survey tools for pharmacists, nurses, and physicians. These validated surveys can be used to assess satisfaction with clinical pharmacy services within the study health care centre and can be shared with other institutions that are introducing or making changes to their services; the survey questions are available from the authors upon request. Survey results may inform decisionmakers about health care professionals' readiness to embrace expanded roles, may provide guidance for making further improvements in the delivery of clinical pharmacy services, and may help to identify areas for staff education and professional development.

We wanted to explore and compare the opinions of pharmacists, nurses, and physicians about clinical pharmacy services. It is not uncommon for differences in perceptions and priorities to exist among health care professions concerning the scope of clinical pharmacy practice. ${ }^{12,13,18,30-32}$ Although there were a number of shared perspectives, a few key differences emerged. All 3 groups of health care professionals strongly agreed that pharmacists should ensure smooth transitions from hospital to home, but nurses and physicians did not support pharmacists' belief that they were the most appropriate health care professionals to provide discharge counselling on medications. It is possible that although many health care professionals recognize pharmacists as "medication experts", their limited availability means that other health care providers must sometimes fulfill this role, particularly outside of regular weekday hours.

However, research supports the value of pharmacists providing discharge counselling. A British study of elderly discharged patients and their caregivers indicated dissatisfaction with the discharge medication information provided by nurses and physicians, whereas those who met with a hospital pharmacist for discharge counselling valued the pharmacist's input. ${ }^{33}$ Cardiac inpatients were significantly more satisfied with the amount of medication information provided by pharmacists, relative to information provided by either nurses or physicians. ${ }^{34}$ Researchers 
This single copy is for your personal, non-commercial use only.

For permission to reprint multiple copies or to order presentation-ready copies for distribution, contact CJHP at cjhpedit@cshp.ca

Table 4. Opinions of Nurses, Physicians, and Pharmacists about Expected Roles of a Clinical Pharmacist

Statement

Health Care Professional Group; Timing; \% with Agree Response* (Mean Rank Score) $\dagger$

\begin{tabular}{|c|c|c|c|c|c|c|c|c|}
\hline \multirow[t]{2}{*}{ Statement } & \multicolumn{3}{|c|}{ Nurses } & \multicolumn{4}{|c|}{ Physicians } & \multirow{2}{*}{$\begin{array}{c}p \text { Value } \\
\text { for Mean } \\
\text { Comparison } \\
\text { (After) }\end{array}$} \\
\hline & $\begin{array}{l}\text { "Before" } \\
\text { Survey } \\
(n=25)\end{array}$ & $\begin{array}{l}\text { "After" } \\
\text { Survey } \\
(n=35)\end{array}$ & $\begin{array}{l}p \text { Value } \\
\text { for Change }\end{array}$ & Pharmacists & $\begin{array}{l}\text { "Before" } \\
\text { Survey } \\
(n=6)\end{array}$ & $\begin{array}{l}\text { "After" } \\
\text { Survey } \\
(n=15)\end{array}$ & $\begin{array}{c}p \text { Value } \\
\text { for Change }\end{array}$ & \\
\hline \multicolumn{9}{|l|}{ General } \\
\hline $\begin{array}{l}\text { Participate in medication } \\
\text { reconciliation }\end{array}$ & $100 \%$ & $97 \%(65.2)$ & $>0.99$ & $71 \%(36.4)$ & $100 \%$ & $100 \%(73.9)$ & $>0.99$ & $<0.001$ \\
\hline $\begin{array}{l}\text { Develop drug protocols and } \\
\text { guidelines specific to unit }\end{array}$ & $64 \%$ & $80 \%(53.1)$ & 0.24 & $79 \%(53.2)$ & $83 \%$ & $87 \%(44.8)$ & $>0.99$ & 0.53 \\
\hline Help to reduce drug costs & $64 \%$ & $69 \%(49.9)$ & 0.79 & $83 \%(53.2)$ & $100 \%$ & $80 \%(52.5)$ & 0.53 & 0.86 \\
\hline $\begin{array}{l}\text { Important role in improving } \\
\text { patient outcomes }\end{array}$ & $84 \%$ & $100 \%(53.4)$ & 0.03 & $100 \%(53.8)$ & $100 \%$ & $93 \%(35.9)$ & $>0.99$ & 0.04 \\
\hline $\begin{array}{l}\text { Provide evidence-based drug } \\
\text { information and } \\
\text { recommendations }\end{array}$ & $92 \%$ & $91 \%(48.4)$ & $>0.99$ & $98 \%(54.1)$ & $100 \%$ & $93 \%(53.0)$ & $>0.99$ & 0.59 \\
\hline \multicolumn{9}{|l|}{ Drug therapy monitoring } \\
\hline $\begin{array}{l}\text { Make changes to antibiotic } \\
\text { doses based on laboratory } \\
\text { values }\end{array}$ & $92 \%$ & $97 \%(51.0)$ & 0.57 & $98 \%(51.0)$ & $100 \%$ & $93 \%(57.7)$ & $>0.99$ & 0.66 \\
\hline $\begin{array}{l}\text { Ensure that patients receive } \\
\text { optimal drug therapy }\end{array}$ & $56 \%$ & $46 \%(30.1)$ & 0.60 & $96 \%(71.3)$ & $67 \%$ & $40 \%(34.8)$ & 0.36 & $<0.001$ \\
\hline $\begin{array}{l}\text { Identify and resolve } \\
\text { drug-related problems as } \\
\text { pharmacists' main role }\end{array}$ & $84 \%$ & $63 \%(35.6)$ & 0.09 & $100 \%(64.4)$ & $83 \%$ & $73 \%(46.2)$ & $>0.99$ & $<0.001$ \\
\hline $\begin{array}{l}\text { Recommend dosage } \\
\text { adjustments }\end{array}$ & $88 \%$ & $97 \%(47.9)$ & 0.30 & $100 \%(61.6)$ & $67 \%$ & $93 \%(27.8)$ & 0.18 & $<0.001$ \\
\hline $\begin{array}{l}\text { Identify, help to resolve, } \\
\text { and document adverse } \\
\text { drug reactions }\end{array}$ & $84 \%$ & $74 \%(48.2)$ & 0.53 & $94 \%(53.3)$ & $100 \%$ & $93 \%(56.2)$ & $>0.99$ & 0.54 \\
\hline $\begin{array}{l}\text { Conduct drug allergy } \\
\text { assessment }\end{array}$ & $88 \%$ & $80 \%(45.9)$ & 0.51 & $89 \%(55.4)$ & $83 \%$ & $93 \%(54.1)$ & 0.50 & 0.27 \\
\hline \multicolumn{9}{|c|}{ Interaction with other health care professionals } \\
\hline $\begin{array}{l}\text { Regular participation on } \\
\text { patient care rounds }\end{array}$ & $96 \%$ & $97 \%(58.2)$ & $>0.99$ & $92 \%(50.0)$ & $67 \%$ & $73 \%(44.5)$ & $>0.99$ & 0.19 \\
\hline $\begin{array}{l}\text { Act as liaison between } \\
\text { pharmacy and nursing units } \\
\text { to solve drug-related problems }\end{array}$ & $100 \%$ & $94 \%(55.3)$ & 0.51 & $98 \%(51.6)$ & $100 \%$ & $93 \%(45.6)$ & $>0.99$ & 0.47 \\
\hline $\begin{array}{l}\text { Provide education to patient } \\
\text { care team on drug-related } \\
\text { topics }\end{array}$ & $92 \%$ & $97 \%(57.6)$ & 0.56 & $96 \%(50.9)$ & $100 \%$ & $93 \%(42.8)$ & $>0.99$ & 0.17 \\
\hline $\begin{array}{l}\text { Participate in research } \\
\text { opportunities }\end{array}$ & $60 \%$ & $60 \%(53.9)$ & $>0.99$ & $72 \%(51.7)$ & $83 \%$ & $80 \%(48.6)$ & $>0.99$ & 0.82 \\
\hline \multicolumn{9}{|c|}{ Involvement in discharge planning } \\
\hline \multicolumn{9}{|c|}{ Liaison with community } \\
\hline $\begin{array}{l}\text { Pharmacists are most } \\
\text { appropriate health care } \\
\text { professionals to provide } \\
\text { medication discharge } \\
\text { counselling }\end{array}$ & $80 \%$ & $74 \%(50.4)$ & 0.76 & $92 \%(59.3)$ & $67 \%$ & $60 \%(30.0)$ & $\begin{array}{r}0.20 \\
>0.99\end{array}$ & 0.001 \\
\hline $\begin{array}{l}\text { Enable smooth transition from } \\
\text { hospital to community }\end{array}$ & $88 \%$ & $85 \%(52.6)$ & $>0.99$ & $98 \%(53.8)$ & $83 \%$ & $93 \%(40.7)$ & 0.50 & 0.21 \\
\hline \multicolumn{9}{|l|}{ Advanced practice roles } \\
\hline $\begin{array}{l}\text { Conduct basic physical } \\
\text { assessments }\end{array}$ & $12 \%$ & $11 \%(44.8)$ & $>0.99$ & $45 \%(63.0)$ & $0 \%$ & $0 \%(29.9)$ & $>0.99$ & $<0.001$ \\
\hline $\begin{array}{l}\text { Certified and available to } \\
\text { administer vaccines }\end{array}$ & $64 \% \neq$ & $60 \% \neq(61.8)$ & 0.79 & $42 \%(47.9)$ & $67 \% \neq$ & $33 \% \neq(43.7)$ & 0.33 & 0.041 \\
\hline $\begin{array}{l}\text { Establish collaborative } \\
\text { practice agreements with } \\
\text { physician }\end{array}$ & $92 \% \neq$ & $97 \% \neq(70.0)$ & 0.57 & $69 \%(44.1)$ & $83 \% \neq$ & $80 \% \neq(38.0)$ & $>0.99$ & $<0.001$ \\
\hline Have prescribing responsibility & $68 \%$ & $82 \%(60.0)$ & 0.23 & $69 \%(53.5)$ & $50 \%$ & $27 \%(24.4)$ & 0.35 & $<0.001$ \\
\hline
\end{tabular}


who surveyed inpatients about the medication information that they received found that the provision of information varied considerably across hospitals. ${ }^{35}$ These authors suggested that this result was related to a lack of clarity among health care professionals about who should be providing this information. ${ }^{35}$

Surgical nurses and physicians were significantly more supportive of pharmacist involvement in medication reconciliation than were pharmacists $(p<0.001)$. It was surprising to see the lack of support among the institution's pharmacists for pharmacist-conducted medication reconciliation, in light of recent recommendations by a pan-Canadian pharmacist task force. ${ }^{36}$ The task force designated 2 clinical pharmacy key performance indicators (cpKPIs) specifically for medication reconciliation (on admission and discharge), out of 8 consensus cpKPIs chosen in prioritizing clinical pharmacy services. ${ }^{36}$ Pharmacists' reluctance to support pharmacist-conducted medication reconciliation may be related to clinical pharmacy services being limited to weekdays only, which may be perceived by pharmacists as a barrier to conducting medication reconciliation.

Pharmacists identified "ensure that patients receive optimal drug therapy" as a key role for pharmacists, whereas the other health care professionals placed less importance on this function. Perhaps nurses and physicians view the pharmacist as one who makes recommendations, as opposed to being the health care professional most responsible for ensuring effective medication therapy. This difference in opinions may also be related to a knowledge gap about pharmacists' training and scope of practice, yet understanding each other's roles is essential for effective interprofessional collaboration. ${ }^{37}$ One physician commented that information from different health care professionals had caused patient confusion. A recent publication analyzing focus group and survey results highlighted both the need for increased pharmacist engagement in interprofessional collaboration and the potential conflict and overlap of roles with other health care professionals. ${ }^{8}$ Educating patients, who are key members of the health care team, about pharmacists' responsibilities may also help to avoid confusion about providers' roles and give patients more opportunities to actively participate in their medication management.

Many changes to Canadian pharmacists' scope of practice have been instituted by regulatory bodies in the past few years, including various levels of prescribing authority and certification to administer vaccines. ${ }^{6,7}$ Although some of these practices have already been implemented in community settings globally, they are less common in hospital settings, ${ }^{20,38,39}$ perhaps because of the particular needs of these practice settings. In the current survey study, there was moderate support for pharmacists administering vaccines, and no physicians and few nurses felt that having pharmacists conduct physical assessments on surgery wards would be beneficial to their practice. Perhaps they believed there was little utility in offering these services on an acute care ward. However, pharmacists practising in primary care settings and in outpatient clinics are increasingly conducting physical assessments as part of their role in monitoring drug therapy. ${ }^{40,41}$

In contrast, surgical nurses expressed strong support for pharmacists having prescribing authority and collaborative practice agreements with physicians. Perhaps nurses held these views for pragmatic reasons. Nursing staff might appreciate the availability of another health care professional to attend to medication-related issues when surgeons and residents are occupied in the operating room. Interestingly, nurses were far more supportive than either pharmacists or physicians of having pharmacists prescribe and engage in collaborative agreements with physicians $(p<0.001)$. Physicians supported the establishment of collaborative practice agreements with pharmacists to a greater degree than they supported giving pharmacists prescribing responsibility ( $80 \%$ versus $27 \%$ ). This may indicate that physicians are comfortable with pharmacists prescribing within the defined framework of a collaborative agreement, but are not comfortable with pharmacists having independent prescribing authority. As well, it is likely that physicians already had experience working with other health care professionals with prescribing authority within collaborative practice agreements, such as nurse practitioners. Similar to many other Canadian hospitals, the nurse practitioner role has been well established in many of the inpatient and outpatient wards of the study hospital. ${ }^{42-44}$

This study had several limitations. The physician group had a small sample size, a low response rate for the "before" survey, and demographic heterogeneity. Residents predominated among respondents to the "after" survey, and their responses may not be generalizable to the larger physician group. Because of limited numbers of study participants, nurses' responses were summarized by the profession overall, and not by intraprofessional roles (e.g., registered nurse versus licensed practical nurse). Therefore, nurses' reported responses may reflect the views of the majority, who were registered nurses. Another limitation may be that pharmacists working in all areas of the hospital completed the survey. However, many pharmacists have been cross-trained to work in multiple clinical areas, including surgery. Finally, limitations related to survey methods include self-reporting, whereby emotional and psychological factors may affect responses. Responses may also reflect a socially desirable result, for example, to deliberately minimize negative effects or enhance positive effects. Nonresponse bias may also occur, whereby health care professionals who are supportive of clinical pharmacy activities may have been more likely to complete the "after" survey, with health care professionals not supportive of these activities being less likely to complete the survey.

Despite these limitations, we believe that the results from this small study provide a solid basis for further interprofessional research involving multiple wards and sites, in addition to the 3 validated survey tools for nurses, pharmacists, and physicians. 


\section{CONCLUSION}

After a pharmacist was introduced on a surgical health care team, nurses and physicians indicated overall high levels of satisfaction with clinical pharmacy services. Differences were observed in opinions related to traditional activities, such as medication reconciliation and discharge counselling, as well as advanced practice roles. The disparities observed highlight the need for further research, using qualitative methods, to explore in depth the factors influencing these differences and to seek solutions to further clarify interprofessional roles.

\section{References}

1. Hepler CD, Strand LM, Tromp D, Sakolchai S. Critically examining pharmaceutical care. J Am Pharm Assoc (Wash). 2002;42(5 Suppl 1):S18-9.

2. Bond CA, Raehl CL. Clinical pharmacy services, pharmacy staffing, and hospital mortality rates. Pharmacotherapy. 2007;27(4):481-93.

3. Chisholm-Burns MA, Kim Lee J, Spivey CA, Slack M, Herrier RN, Hall-Lipsy E, et al. US pharmacists' effect as team members on patient care: systematic review and meta-analyses. Med Care. 2010;48(10):923-33.

4. Kaboli PJ, Hoth AB, McClimon BJ, Schnipper JL. Clinical pharmacists and inpatient medical care: a systematic review. Arch Intern Med. 2006; 166(9):955-64.

5. Makowsky MJ, Koshman SL, Midodzi WK, Tsuyuki RT. Capturing outcomes of clinical activities performed by a rounding pharmacist practicing in a team environment: the COLLABORATE study. Med Care. 2009; 47(6):642-50.

6. Blueprint for pharmacy: transition in a new era. Ottawa $(\mathrm{ON})$ : Canadian Pharmacists' Association; 2015 [cited 2016 Mar 31]. Available from: https://www.pharmacists.ca/cpha-ca/assets/File/pharmacy-in-canada/ blueprint/Blueprint\%20Transition\%20Report_2015_ENG.pdf

7. Law MR, Ma T, Fisher J, Sketris IS. Independent pharmacist prescribing in Canada. Can Pharm J. 2012;145(1):17,23.e1.

8. Schindel TJ, Yuksel N, Breault R, Daniels J, Varnhagen S, Hughes CA. Perceptions of pharmacists' roles in the era of expanding scopes of practice. Res Social Adm Pharm. 2017;13(1):148-61. Epub 2016 Mar 16.

9. Merten JA, Shapiro JF, Gulbis AM, Rao KV, Bubalo J, Lanum S, et al. Utilization of collaborative practice agreements between physicians and pharmacists as a mechanism to increase capacity to care for hematopoietic stem cell transplant recipients. Biol Blood Marrow Transplant. 2013; 19(4):509-18.

10. Tonna AP, Stewart D, West B, McCaig D. Pharmacist prescribing in the UK-a literature review of current practice and research. J Clin Pharm Ther. 2007;32(6):545-56.

11. Cruthirds DL, Hughes PJ, Weaver S. Value of pharmacy services to the healthcare system: an interdisciplinary assessment. Int J Pharm Pract. 2013; 21(1):38-45.

12. Fairbanks RJ, Hildebrand JM, Kolstee KE, Schneider SM, Shah MN. Medical and nursing staff highly value clinical pharmacists in the emergency department. Emerg Med J. 2007;24(10):716-8.

13. Gillespie U, Alassaad A, Henrohn D, Garmo H, Hammarlund-Udenaes M, Toss $\mathrm{H}$, et al. A comprehensive pharmacist intervention to reduce morbidity in patients 80 years or older: a randomized controlled trial. Arch Intern Med. 2009;169(9):894-900

14. Ariano RE, Demianczuk RH, Danzinger RG, Richard A, Milan H, Jamieson B. Economic impact and clinical benefits of pharmacist involvement on surgical wards. Can J Hosp Pharm. 1995;48(5):284-9.

15. Chevalier B, Neville HL. Evaluating clinical pharmacy services on a surgical patient-care area: a nurses' satisfaction survey. Int J Pharm Pract. 2011; 19(1):61-9.

16. Lacaria K, Balen R, Frighetto L, Lau T, Naurmann T, Jewesson P. Perceptions of the professional pharmacy services in a major Canadian hospital: a comparision of stakeholder groups. Longwoods Rev. 2004;2(1):8-19.
17. MacLaren R, Brett McQueen R, Campbell J. Clinical and financial impact of pharmacy services in the intensive care unit: pharmacist and prescriber perceptions. Pharmacotherapy. 2013;33(4):401-10.

18. Cufar A, Mrhar A, Robnik-Sikonja M. Assessment of surveys for the management of hospital clinical pharmacy services. Artif Intell Med. 2015; 64(2):147-58

19. Hoti K, Hughes J, Sunderland B. Expanded prescribing: a comparison of the views of Australian hospital and community pharmacists. Int J Clin Pharm. 2013;35(3):469-75.

20. Hutchison M, Lindblad A, Guirguis L, Cooney D, Rodway M. Survey of Alberta hospital pharmacists' perspectives on additional prescribing authorization. Am J Health Syst Pharm. 2012;69(22):1983-92.

21. Wheeler A, Crump K, Lee M, Li L, Patel A, Yang R, et al. Collaborative prescribing: a qualitative exploration of a role for pharmacists in mental health. Res Social Adm Pharm. 2012;8(3):179-92.

22. About us [website]. Halifax (NS): Capital Health; 2015 [cited 2016 Mar 31]. Available from: www.cdha.nshealth.ca/about-us

23. Hospital pharmacists: information paper on direct patient care and beyond. Ottawa (ON): Canadian Society of Hospital Pharmacists; 2010 [cited 2016 Mar 31]. Available from: www.cshp.ca/productsServices/officialPublications/ subject_e.asp

24. Model standards of practice for Canadian pharmacists. Ottawa $(\mathrm{ON})$ : National Association of Pharmacy Regulatory Authorities; 2009 [cited 2016 Mar 31]. Available from: http://napra.ca/Content_Files/Files/Model_ Standards_of_Prac_for_Cdn_Pharm_March09_Final_b.pdf

25. Schommer JC, Wenzel RG, Kucukarslan SN. Evaluation of pharmacists' services for hospital inpatients. Am J Health Syst Pharm. 2002;59(17):1632-7.

26. Schommer JC, Kucukarslan SN. Measuring patient satisfaction with pharmaceutical services. Am J Health Syst Pharm. 1997;54(23):2721-32; quiz 2741-3.

27. Lustig A, Sokol R, Peled R, David T. Nurses' evaluation of pharmacists' services—a hospital survey. Pharm World Sci. 2005;27(4):290-5.

28. Tavakol M, Dennick R. Making sense of Cronbach's alpha. Int J Med Educ. 2011;2:53.

29. George D, Mallery P. SPSS for Windows step by step: a simple guide and reference. 4th ed. Boston (MA): Allyn and Bacon; 2003.

30. Clark TR. Gap analysis: assessing the value perception of consultant pharmacist services and the performance of consultant pharmacists. Consult Pharm. 2008;23 Suppl C:3-15.

31. Coralic Z, Kanzaria HK, Bero L, Stein J. Staff perceptions of an on-site clinical pharmacist program in an academic emergency department after one year. West J Emerg Med. 2014;15(2):205-10.

32. Halvorsen KH, Stensland P, Granas AG. A qualitative study of physicians' and nurses' experiences of multidisciplinary collaboration with pharmacists participating at case conferences. Int J Pharm Pract. 2011;19(5):350-7.

33. Knight DA, Thompson D, Mathie E, Dickinson A. 'Seamless care? Just a list would have helped!' Older people and their carer's experiences of support with medication on discharge home from hospital. Health Expect. 2011; 16(3):277-91.

34. Auyeung V, Patel G, McRobbie D, Weinman J, Davies G. Information about medicines to cardiac in-patients: patient satisfaction alongside the role perceptions and practices of doctors, nurses and pharmacists. Patient Educ Couns. 2011;83(3):360-6.

35. Krska J, Morecroft C. Informing patients about medicines-a hospital inpatient survey in England. Patient Educ Couns. 2013;90(2):276-8.

36. Fernandes O, Gorman SK, Slavik RS, Semchuk WM, Shalansky S, Bussières $\mathrm{JF}$, et al. Development of clinical pharmacy key performance indicators for hospital pharmacists using a modified Delphi approach. Ann Pharmacother. 2015;49(6):656-69.

37. A national interprofessional competency framework. Vancouver (BC): Canadian Interprofessional Health Collaborative; 2010 [cited 2016 Mar 31]. Available from: www.cihc.ca/files/CIHC_IPCompetencies_Feb1210.pdf

38. Makowsky MJ, Guirguis LM, Hughes CA, Sadowski CA, Yuksel N. Factors influencing pharmacists' adoption of prescribing: qualitative application of the diffusion of innovations theory. Implement Sci. 2013;8:109. 
39. Heck T, Gunther M, Bresee L, Mysak T, Mcmillan C, Koshman S. Independent prescribing by hospital pharmacists: patterns and practices in a Canadian province. Am J Health Syst Pharm. 2015;72(24):2166-75.

40. Heisler M, Hofer TP, Schmittdiel JA, Selby JV, Klamerus ML, Bosworth $\mathrm{HB}$, et al. Improving blood pressure control through a clinical pharmacist outreach program in patients with diabetes mellitus in 2 high-performing health systems: the adherence and intensification of medications cluster randomized, controlled pragmatic trial. Circulation. 2012;125(23):2863-72.

41. Martinez AS, Saef J, Paszczuk A, Bhatt-Chugani H. Implementation of a pharmacist-managed heart failure medication titration clinic. Am J Health Syst Pharm. 2013;70(12):1070-6.

42. Forchuk C, Kohr R. Prescriptive authority for nurses: the Canadian perspective. Perspect Psychiatr Care. 2009;45(1):3-8.

43. Van Soeren M, Hurlock-Chorostecki C, Reeves S. The role of nurse practitioners in hospital settings: implications for interprofessional practice. J Interprof Care. 2011;25(4):245-51.

44. Mian O, Koren I, Rukholm E. Nurse practitioners in Ontario primary healthcare: referral patterns and collaboration with other healthcare professionals. J Interprof Care. 2012;26(3):232-9

Bernadette Chevalier, BSc(Hon), BScPharm, ACPR, was, at the time of this study, a Drug Utilization Pharmacist with the Nova Scotia Health Authority, Halifax, Nova Scotia. She is now a PhD candidate with the School of Pharmacy, Pharmacy Australia Centre of Excellence, The University of Queensland, Woolloongabba, Brisbane, Australia.
Heather L Neville, BScPharm, MSc, is Drug Utilization Pharmacist and Pharmacy Research Coordinator, Nova Scotia Health Authority, Halifax, Nova Scotia.

Kara Thompson, BSc, MSc, is a Biostatistician with the Research Methods Unit, Nova Scotia Health Authority, Halifax, Nova Scotia.

Lisa Nodwell, BScPharm, ACPR, is a Clinical Pharmacist with the Nova Scotia Health Authority, Halifax, Nova Scotia.

Michael MacNeil, PharmD, ACPR, is a Surgery Pharmacist with the Nova Scotia Health Authority, Halifax, Nova Scotia.

Competing interests: None declared.

Address correspondence to:

Bernadette Chevalier

School of Pharmacy

Pharmacy Australia Centre of Excellence

The University of Queensland

20 Cornwall Street

Woolloongabba, Brisbane, Australia 4012

e-mail: b.chevalier@uq.edu.au

Funding: This research was funded internally by the authors' pharmacy department (Nova Scotia Health Authority); there was no external funding.

Acknowledgments: The authors appreciate the assistance of Jessica Killen for data entry, Holly Foot for additional statistical advice and computation, Bernadette Watson for advice on survey validation, and the health care professionals who completed the surveys.

\section{CJHP Subscriptions 2017 / Abonnements au JCPH 2017}

The Canadian Journal of Hospital Pharmacy (CJHP) online is included as a benefit of CSHP membership. All prices are in Canadian funds.

L'abonnement à la version électronique du Le Journal canadien de la pharmacie hospitalière $(J C P H)$ publiée en ligne est inclus dans les droits d'inscription à la SCPH. Tous les prix sont en dollars canadiens.

\begin{tabular}{|c|c|c|}
\hline $\begin{array}{l}\text { Subscriber group / } \\
\text { Groupe d'abonnés }\end{array}$ & $\begin{array}{l}\text { Individual Online Subscription / } \\
\text { Abonnement individuel en ligne }\end{array}$ & $\begin{array}{l}\text { Institutional Online Subscriptions / } \\
\text { Abonnement institutionnel en ligne }\end{array}$ \\
\hline & $\begin{array}{l}\$ 160.00 \text { per year, plus GST or HST } \\
160.00 \text { \$ par an, plus TPS ou TVH }\end{array}$ & $\begin{array}{l}\$ 480.00 \text { per year, plus GST or HST } \\
480.00 \text { \$ par an, plus TPS ou TVH }\end{array}$ \\
\hline
\end{tabular}

If you would like to purchase a subscription, please fill-out our CJHP 2017 Subscription Application Form, which can be found on the CJHP website: www.cjhp-online.ca. Please direct any comments or questions to publications@cshp.ca.

Si vous désirez vous abonner, veuillez remplir le formulaire d'abonnement au JCPH 2017. Vous pouvez l'obtenir en visitant le site Web du JCPH : www.cjhp-online.ca. Pour tout commentaire ou toute question, veuillez vous adresser à publications@cshp.ca. 